\title{
ROOT SYSTEMS AND SOIL MICROBIAL BIOMASS UNDER NO-TILLAGE SYSTEM
}

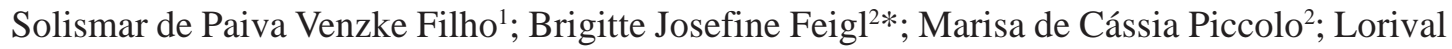 \\ Fante Jr. ; Marcos Siqueira Neto ${ }^{3}$; Carlos Clemente Cerri ${ }^{2}$ \\ ${ }^{1}$ USP/ESALQ - Programa de Pós-Graduação em Microbiologia Agrícola, C.P. 09 - 13418-900 - Piracicaba, SP - \\ Brasil. \\ ${ }^{2}$ USP/CENA - Lab. Biogeoquímica Ambiental, C.P. 96 - 13400-970 - Piracicaba, SP - Brasil. \\ ${ }^{3}$ UNIMEP - Faculdade de Engenharia, Arquitetura e Urbanismo, Campus SBO, Rod. Sta. Bárbara/Iracemápolis, \\ km 1 - 13450-000 - Santa Bárbara d'Oeste, SP - Brasil. \\ ${ }^{4}$ USP/CENA - Programa de Pós-Graduação em Energia Nuclear na Agricultura. \\ *Corresponding author <beduardo@cena.usp.br>
}

\begin{abstract}
Some root parameters such as distribution, length, diameter and dry matter are inherent to plant species. Roots can influence microbial population during vegetative cycle through the rhizodeposits and, after senescence, integrating the soil organic matter pool. Since they represent labile substrates, especially regarding nitrogen, they can determine the rate of nutrient availability to the next crop cultivated under no-tillage (NT). The root systems of two crop species: maize (Zea mays L.) cultivar Cargill 909 and soybean [Glycine max (L.) Merr.] cultivar Embrapa 59, were compared in the field, and their influence on spatial distribution of the microbial $\mathrm{C}$ and $\mathrm{N}$ in a clayey-textured Typic Hapludox cultivated for 22 years under NT, at Tibagi, State of Paraná (PR), Brazil, was determined. Digital image processing and nail-plate techniques were used to evaluate 40 plots of a $80 \times 50 \times 3 \mathrm{~cm}$ soil profile. It was observed that $36 \%$ and $30 \%$ of the maize and soybeans roots, respectively, are concentrated in the 0 to $10 \mathrm{~cm}$ soil layer. The percent distribution of root dry matter was similar for both crops. The maize roots presented a total of $1,324 \mathrm{~kg} \mathrm{C} \mathrm{ha}^{-1}$ and $58 \mathrm{~kg} \mathrm{~N} \mathrm{ha}^{-1}$, with higher root dry matter density and more roots in decomposition in the upper soil layer, decreasing with depth. The soybean roots (392 kg C ha-1 and $21 \mathrm{~kg} \mathrm{~N} \mathrm{ha}^{-1}$ ) showed higher number of thinner roots and higher density per length unity compared to the maize. The maize roots enhanced microbial-C down to deeper soil layers than did the soybean roots. The microbial $\mathrm{N}$ presented a better correlation with the concentration of thin active roots and with roots in decomposition or in indefinite shape, possibly because of higher concentration of $\mathrm{C}$ and $\mathrm{N}$ easily assimilated by soil microorganisms.
\end{abstract}

Key words: root distribution, maize, soybean, carbon, nitrogen

\section{SISTEMAS RADICULARES E BIOMASSA MICROBIANA DO SOLO SOB PLANTIO DIRETO}

RESUMO: Parâmetros radiculares como distribuição, comprimento, diâmetro e matéria seca são inerentes a cada espécie de planta. As raízes podem influenciar a população microbiana durante o ciclo vegetativo através das rizodeposições e, após a senescência, integrando a matéria orgânica do solo. Pelo fato de representarem um substrato lábil, especialmente de nitrogênio, podem ditar o ritmo da disponibilidade de nutrientes na seqüência de culturas sob o sistema de plantio direto (SPD). A comparação dos sistemas radiculares do milho (Zea mays L.), cultivar Cargill 909 e da soja [Glycine max (L.) Merr.], cultivar Embrapa 59, e sua influência sobre a distribuição espacial do C e N microbianos foi feita em um Latossolo Vermelho-Escuro, textura argilosa, cultivado durante 22 anos sob SPD, no município de Tibagi (PR). Técnicas de processamento de imagens e de placa de pregos foram empregadas na avaliação de 40 quadrículas de um perfil de $80 \times 50 \times 3 \mathrm{~cm}$, revelando que $36 \%$ das raízes de milho e $30 \%$ das raízes de soja estão concentradas na camada $0-10 \mathrm{~cm}$ do solo. A distribuição percentual no perfil do solo de matéria seca radicular foi semelhante nas duas culturas. O sistema radicular do milho apresentou $1.324 \mathrm{~kg} \mathrm{C} \mathrm{ha}^{-1} \mathrm{e}$ $58 \mathrm{~kg} \mathrm{~N} \mathrm{ha}{ }^{-1}$, com maior densidade por matéria seca e de raízes em vias de decomposição na camada superficial do solo, decrescendo com a profundidade. O sistema radicular da soja (392 kg C ha-1 e 21 kg N $\mathrm{ha}^{-1}$ ) teve contribuição maior de raízes finas e de densidade por comprimento do que do milho. O efeito das raízes do milho sobre o $\mathrm{C}$ microbiano alcançou camadas mais profundas do que o das raízes da soja. O N microbiano apresentou melhor correlação com a concentração de raízes finas ativas e com as raízes em decomposição ou de forma indefinida, provavelmente em função da maior quantidade de C e $\mathrm{N}$ de fácil assimilação pelos microrganismos.

Palavras-chave: distribuição das raízes, milho, soja, carbono, nitrogênio 


\section{INTRODUCTION}

No-tillage systems (NT) can potentially increase soil organic C. Several studies have shown that the seeding procedure without previous soil revolving, crop rotation and residues left over the soil surface, may result in increasing soil organic C (Staley et al., 1988; Carter, 1992; Sá et al., 2001). Using ${ }^{14} \mathrm{C}$-marked oat plants, Gale \& Cambardella (2000) demonstrated that one year after plant residue incorporation to the soil, $42 \%$ of remnant residues in the soil were originated from roots, whereas only $16 \%$ were from plant residues left over the soil surface. Crop root systems fill less than $1 \%$ of the soil volume (Barber, 1995), but exert important influence on the soil/rhizosphere chemical, physical and/or biological characteristics (Rovira, 1979), and also increase carbon reservoir in soils under NT system.

From agronomic stand point, large and extensive root systems are desirable. Root densities in the soil as related to plant species varies from 1 to $5 \mathrm{~cm} \mathrm{~cm}^{-3}$ in superficial soil layers for annual crops, and up to $50 \mathrm{~cm} \mathrm{~cm}^{-}$ ${ }^{3}$ for perennial grasses (Barber, 1995). The biological relevance stands on the quantity and quality of dry matter produced. It is estimated that about $60 \%$ of the photoassimilates are transported to the roots, from which $50 \%$ are released as $\mathrm{CO}_{2}$ during respiration and $50 \%$ is destined to root growth or released into the soil as exudates, mucilage, lisates, and other forms, the so, called rhizodeposits (Bolton Jr. et al., 1993; Moreira \& Siqueira, 2002), an energy source for microorganisms.

The enhancing effect of roots on microbial biomass depends on the soil characteristics and the physiology, morphology and architecture of each plant rooting system. Overall, legumes present more pronounced effect on a root-dry-matter-unit basis; however, grasses present higher effect on a total-root-dry-matter basis, because of their larger root systems and faster root growth and renovation (Rovira, 1979; Lynch, 1982). Studying seven different crop rotation and succession systems in the State of Rio Grande do Sul (Cattelan \& Vidor, 1990), observed that the systems with the highest dry matter yield and residue accumulation, mostly composed of grasses, presented the highest microbial-C contents in the $0-5 \mathrm{~cm}$ soil layer, what was attributed partly to an enhancing effect of rhizosphere on microbial growth.

Studies on root system evaluation in grain crops in Brazilian soils are scarce, mainly under no-tillage system. The quantification of root systems usually involves expensive procedures, concerning time, labor and costs. However, it is an efficient method to evaluate land use effect over soil compaction and plant root growth. More recently quantification and distribution of root system have turned easier with the development of new techniques, such as the digital image processing. In this context, this research work aimed at comparing the distribu- tion, length, diameter and dry matter yield of root systems of a grass (maize) and a legume (soybeans) field crop evaluating the influence of such variables upon the microbial $\mathrm{C}$ and $\mathrm{N}$ contents of a soil cultivated under notillage system.

\section{MATERIAL AND METHODS}

\section{Sampling area location and crop management}

Experiments were carried out at Tibagi, State of Paraná, Brazil $\left(24^{\circ} 26^{\prime}\right.$ S; $50^{\circ} 23^{\prime}$ W) in a clayey-textured Typic Hapludox (420, 80 and $500 \mathrm{~g} \mathrm{~kg}^{-1}$ of clay, silt and sand, respectively). Area, managed under no-tillage system for 22 years, and submitted to crop rotation with soybeans, maize, wheat and black-oats during the last ten years. The area's soil chemical and physical characteristics were descrited in Sá (2001). Fertilizers were applied based on soil analysis and according to crop species and variety: (1) plots planted with maize cultivar Cargill 909 plots received $400 \mathrm{~kg} \mathrm{ha}^{-1}$ of N-P-K (20-00-10) at seeding, and 20 days later, $200 \mathrm{~kg} \mathrm{ha}^{-1}$ of side-dressed ammonium sulfate; (2) plots panted with soybean cultivar Embrapa 59 received $200 \mathrm{~kg} \mathrm{ha}^{-1}$ of simple-superphosphate, $150 \mathrm{~g} \mathrm{ha}^{-1}$ of manganese, $2.5 \mathrm{~g} \mathrm{ha}^{-1}$ of cobalt and $15 \mathrm{~g} \mathrm{ha}^{-1}$ of molybdenum. Prior to seeding, soybean seeds were inoculated with Rhizobium $150 \mathrm{~g} 100 \mathrm{~kg}^{-1}$ seed and received Fiprolin insecticide (50 g a.i. $100 \mathrm{~kg}^{-1}$ seed).

\section{Evaluation of maize and soybean root systems}

Sampling of root system was made when maize plants were in the tassel emission stage and soybean plants in the R1 stage of Fehr et al. (1971), corresponding to the initial flowering stage. Three trenches were opened in each plot, and root systems were evaluated in one side of the soil profile, perpendicularly to plant rows. Two consecutive root samplings were made in the maize crop and three in the soybean crop.

Digital image processing (Crestana et al., 1994; Fante Jr., 1997) in association with nail-plate technique (Schurmann \& Goedewaagen, 1971; Bohm, 1979), were used to determinate root distribution, root length, diameter and dry matter in the soil profile. The soil profile was recorded at one side of the trench with a video camera, and images were taken separately at each $10 \times 10 \mathrm{~cm}$ square, delimitated by nylon strings within an $80 \times 50$ $\mathrm{cm}$ wooden frame fixed at the soil profile from the surface edge. A total of 40 images per profile and 120 images per crop were digitalized and processed, initially in a graphic editor program to improve image quality; thereafter, in the "integrated system for root and soil vegetation covering evaluation" (SIARCS) program (Crestana et al., 1994). The SIARCS was used to determine spatial root distribution in a root length basis. After saving the image in a computer file, the nail-plate technique was applied in the same side of the soil profile trench as fol- 
lows: a $80 \times 50 \mathrm{~cm}$ plate was fixed with 3 -cm long nails, $2.5 \times 2.5 \mathrm{~cm}$ uniformly spaced. The soil layer plus roots corresponding to each $2.5 \mathrm{~cm}$ nail square was collected from the profile $\left(300 \mathrm{~cm}^{3}\right)$, resulting in 40 samples from each trench, and 120 samples per crop.

In the laboratory, soil samples were sieved through a $0.5-\mathrm{cm}$ screen and roots were separated from soil using tweezers. Soil samples were analyzed for microbial and total $\mathrm{C}$ and $\mathrm{N}$ contents. Root samples were rinsed to completely remove soil particles, separated subjectively into thinner and thicker roots and put in a recipient with water over a scanner, in order to obtain digital images. These images were processed as previously described and the following determinations were made: RDMD = root dry matter density (intact root dry matter per volume of soil sample); RLD = root length density (root length per volume of soil sample); unshapely or decomposing root dry matter; and root diameter, through calculation, dividing root length by the root surface area (Fante Jr., 1997). Root dry matter was determined after oven drying samples at $60^{\circ} \mathrm{C}$ during 24 hours.

\section{Determination of soil and microbial $\mathrm{C}$ and $\mathrm{N}$ contents originated from roots}

Root samples were ground in an inox Willey type grinder to pass a $150 \mathrm{~mm}$ screen and submitted to routine analysis for total $\mathrm{C}$ and $\mathrm{N}$ by dry combustion in a CN-2000 LECO $^{\circledR}$ autoanalyzer. Air dried soil samples were submitted to the same procedures to determine total soil $\mathrm{C}$ and $\mathrm{N}$ contents.

The microbial C contents were evaluated by the fumigation-extraction method (Brookes et al., 1985; Vance et al., 1987), using the correction factor $k_{\mathrm{EC}}=0.33$ (Sparling \& West, 1988); and the microbial N contents by the ninhydrin reactive compound quantification method (Joergensen \& Brookes, 1990), using the conversion factor $k_{\mathrm{EN}}=6.5$ (Sparling et al., 1993).

\section{Statistical analysis}

Means obtained from three replications (trenchs) of the eight columns $(10 \times 10 \mathrm{~cm})$ in each of the five soil layers, were compared by the Student $\mathrm{T}$ test. The SASstatistical analysis routine procedure for T test (SAS Institute, 1987) was used and the two groups of observations were independently compared. Pearson simple linear correlation analysis (CORR procedure of SAS) was also applied to the microbial $\mathrm{C}$ and $\mathrm{N}$ contents and root parameters data.

\section{RESULTS AND DISCUSSION}

\section{Root distribution, length, diameter and dry matter of maize and soybeans root systems}

For the maize crop, plants spaced $80-\mathrm{cm}$, there was a predominance of roots longer than $1 \mathrm{~cm}$ (Figure 1). For the soybean crop, plants spaced $40 \mathrm{~cm}$ predomi- nated roots shorter than $1 \mathrm{~cm}$. In the 4 -cm soil surface layer, the maize roots extended over the $80 \mathrm{~cm}$ distance between plants and were mostly longer than $2 \mathrm{~cm}$, while soybean roots were shorter than $1 \mathrm{~cm}$.

The maize crop presented $36 \%$ of total roots concentrated in the $0-10 \mathrm{~cm}$ soil layer, and the soybean crop showed 30\%. However, there were significant differences in root characteristics, since maize had $28 \%$ of thin roots in this layer, and soybeans, 92\% (Figure 2). Thin roots had definite diameter $\leq 0.12 \mathrm{~cm}$. The greater number of thin roots found in soybean plants provide higher contact with the soil matrix surface area, enabling the root system better exploration of the soil. For the microorganisms, especially bacteria, this is a desirable character given their low mobility, which, however, do not guarantee a measurable effect on microorganisms, mainly saprophytes.

The soil under soybean crop presented 1.7 to 2.8fold higher root length density $\left(\mathrm{RLD} \mathrm{cm}{ }^{-3}\right)$ soil, than that observed under the maize crop (Figure 3). However, density did not decrease with depth. As already discussed, the soybean thin roots are the main contributors to this high RLD.

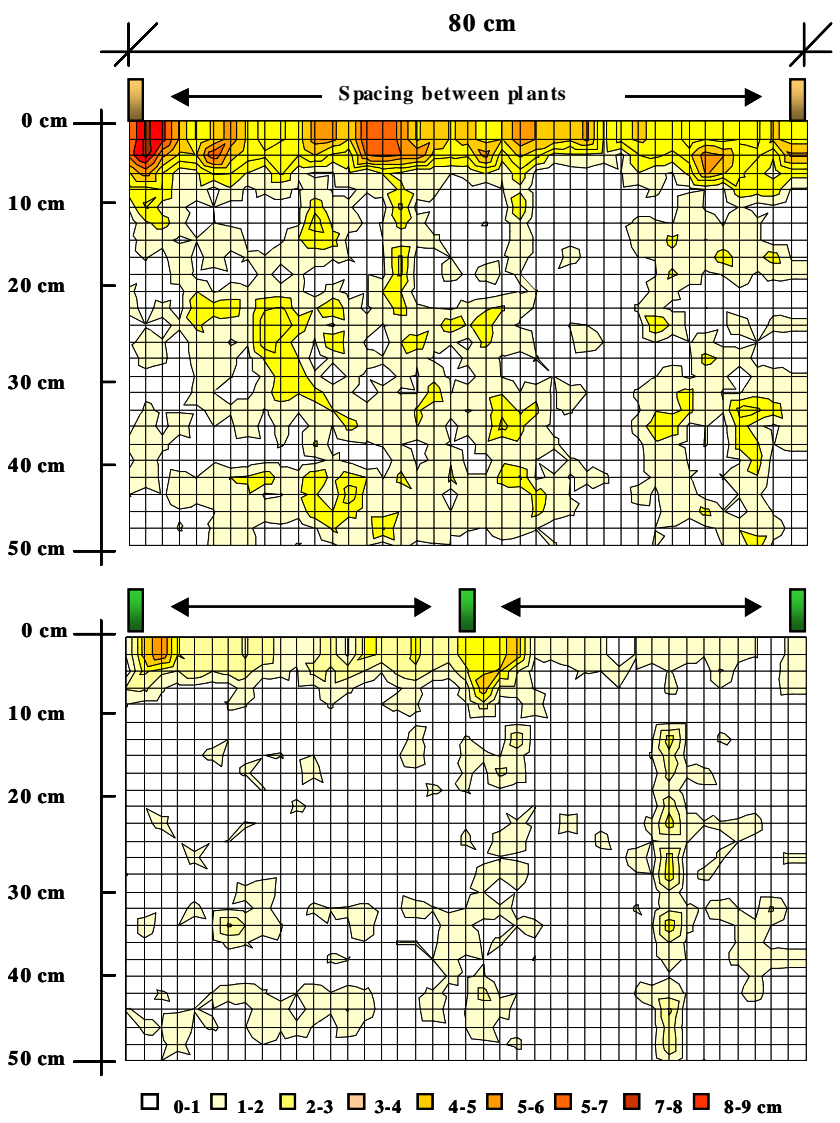

Figure 1 - Graphic representation of root systems distribution: (a) maize and (b) soybeans, in the soil profile $(50 \times 80 \mathrm{~cm})$. Figures were set up with data of root length (average of three replications) determined by the SIARCS program in $2 \times 2 \mathrm{~cm}$ segment regions from images obtained from $10 \times 10 \mathrm{~cm}$ soil profile squares filming. 
The average root dry matter density (RDMD) per soil unity volume $\left(\mathrm{cm}^{3}\right)$ of soybean was statistically equal to the maize, except for the $30-40 \mathrm{~cm}$ soil layer (Figure 3). However, the maize roots presented, respectively, 78
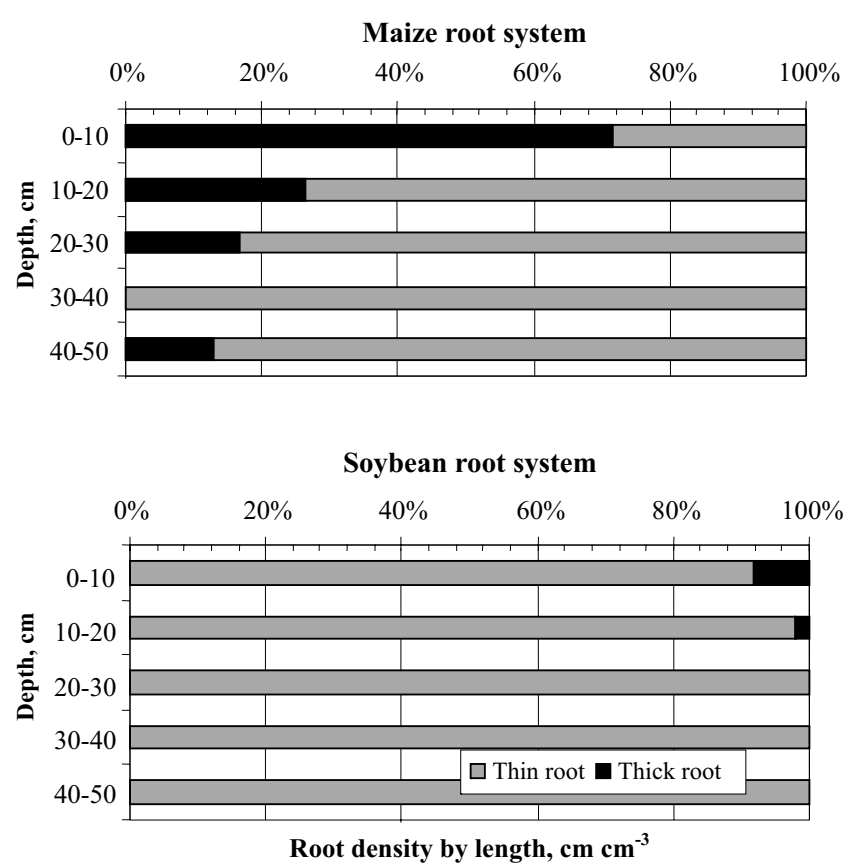

Figure 2 - Contribution of thick roots (diameter $>0.12 \mathrm{~cm}$ ) and thin roots (diameter $\leq 0.12 \mathrm{~cm}$ ) in the maize and soybean root systems.

Root length density $-\mathrm{cm} \mathrm{cm}^{-3}$

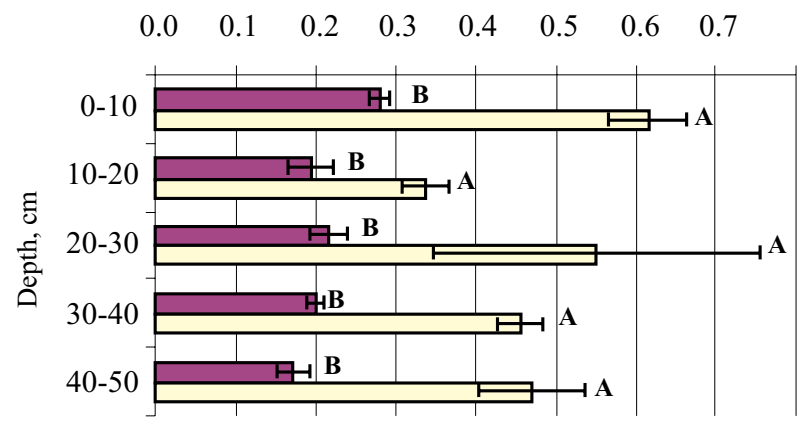

Decomposing root dry matter, $\mathrm{mg} \mathrm{cm}^{-3}$

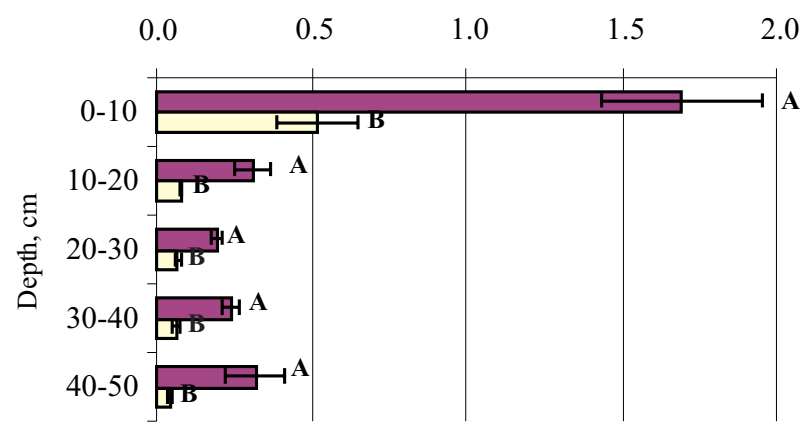

and $134 \%$ more RDMD than soybean roots in the $0-10$ and $10-20 \mathrm{~cm}$ soil layers. The root distribution analysis between the two crops (Figure 1) and the increase in root diameter observed for maize in the deeper layers compared to the 20-30 cm layer, suggest that soil compaction might have occurred at the $15 \mathrm{~cm}$ layer. Soybean presented higher RDMD in the deeper layers than maize, probably because their thinner roots went through this compacted soil layer more easily, as already observed for another crops (Shierlaw \& Alston, 1984). Consequently, the soil constraint to root penetration was less effective for the soybean compared to the maize plants.

The root diameters determined for the soybean and maize plants did not differ in the superficial soil layer $(0-10 \mathrm{~cm})$, but in deeper layers, the maize root diameter was 0.8-2.8 times larger than that of soybean (Figure 3). This root physical characteristic assumes high relevance for the sustainability of the no-tillage system, because in this system, with no soil revolving and intensive machinery traffic (Tormena, 1996), the presence of high diameter channels set up by roots and fauna, open ways for water infiltration and gas exchange.

Maize plants showed 3.5-fold the quantity of unshapely or decomposing roots in comparison to soybean plants (Figure 3). Actually, grasses tend to present higher rates of root renovation than legumes (Lynch, 1982), resulting in higher dry matter accumulation at the end of plant cycle.

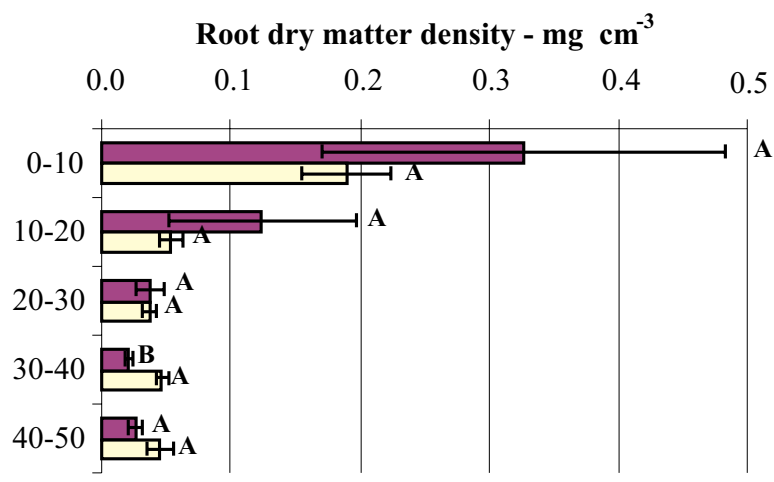

Root diameter, $\mathrm{cm}$

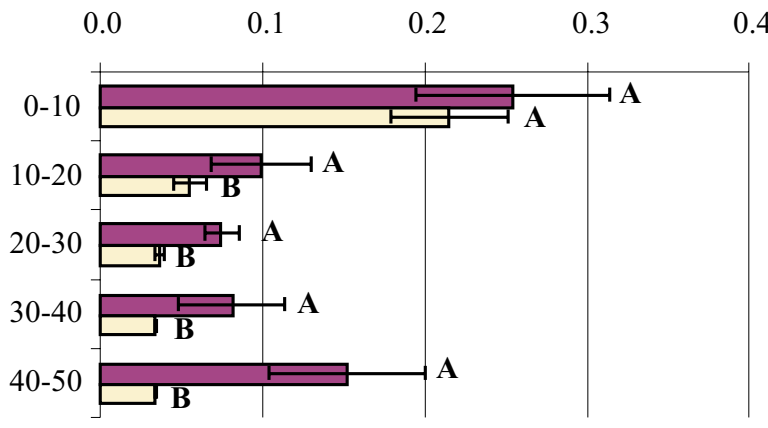

Maize

Soybean

Figure 3 - Physical characteristics of maize and soybean roots cultivated in a soil under no-tillage system (average of three replications). Means \pm standard deviation followed by the same letters, in the same depth, do not differ by Student's T test (0.05). 
The maize root system accumulated total $\mathrm{C}$ contents of $1,324 \mathrm{~kg} \mathrm{ha}^{-1}$ and total $\mathrm{N}$ contents of $58 \mathrm{~kg} \mathrm{ha}^{-1}$ in the $0-50 \mathrm{~cm}$ soil layer, while the soybean roots accumulated 392 nd $20.7 \mathrm{~kg} \mathrm{ha}^{-1}$ of $\mathrm{C}$ and N, respectively (Table 1); maize plants accumulated 3.5-fold $\mathrm{C}$ and 2.5 -fold $\mathrm{N}$ in comparison to soybean. Maize is a C4 plant, with high photosynthetic efficiency, producing amounts of shoot and root dry matter several times higher than soybeans. Nevertheless, the percent distribution of total root dry matter (active plus decomposing roots) in the evaluated soil layers was similar between the two crops $(61,13,7,8$, and $10 \%$ for maize plants; $61,12,9,10$, and $8 \%$, for soybean plants) by the nail-plate method. The effects of such characteristics on the microbial biomass, keeping the respective crop dry matter proportions, had similar distribution in the soil under no-tillage system. Not only the quantity and quality of roots and rhizodeposits, but also their position in the soil profile, are important for the microorganisms.

The $\mathrm{C}$ and $\mathrm{N}$ quantities in the maize and soybean thin roots at sampling were similar. Maize roots presented $84 \mathrm{~kg} \mathrm{ha}^{-1}$ of $\mathrm{C}$ and $4.3 \mathrm{~kg} \mathrm{ha}^{-1}$ of $\mathrm{N}$; soybeans presented, $90 \mathrm{~kg} \mathrm{ha}^{-1}$ of $\mathrm{C}$ and $4.5 \mathrm{~kg} \mathrm{ha}^{-1}$ of N. On the other hand, the thick roots of maize accumulated more than twice the quantity of C (112 $\left.\mathrm{kg} \mathrm{ha}^{-1}\right)$ in comparison to soybean roots $\left(50 \mathrm{~kg} \mathrm{ha}^{-1}\right.$ ) (Table 1). Nevertheless, the major contribution of $\mathrm{C}$ and $\mathrm{N}$ to the soil comes from the decomposing roots. The maize decomposing roots presented $1,127 \mathrm{~kg}$ ha ${ }^{-1}$ of $\mathrm{C}$ and $49.2 \mathrm{~kg} \mathrm{ha}^{-1}$ of $\mathrm{N}$ in the $0-50 \mathrm{~cm}$ soil layer, a much larger quantity compared to the soybean decomposing roots (252 kg ha ${ }^{-1}$ of $\mathrm{C}$ and $14.6 \mathrm{~kg} \mathrm{ha}^{-1}$ of $\mathrm{N}$ ).

The decomposing roots in both crops are the main quantitative source of nutrients for the microorganisms. Consequently, the nutrient mineralization and immobilization processes may occur simultaneously in the soil, mainly with the mineral- $\mathrm{N}$ forms. However, the severity of the impact of these processes on the remnant soil organic matter has been object of controversy. There are reports of increase (Billes \& Bottner, 1981; Cheng \& Coleman, 1990; Qian et al., 1997), decrease (Jenkinson, 1977; Sparling et al., 1982; Fisher \& Gosz, 1986), and maintenance (Cuenca et al., 1983) of the soil organic matter decomposition rate in the presence of root systems.
These divergent results might be related to the diversity of soils used, plant species, analytical method and complexity of soil-plant interactions influencing the study and interpretation of the soil organic matter dynamics.

\section{Microbial biomass in the soil profile}

The average microbial $\mathrm{C}$ content in each soil layer under the maize rhizosphere influence decreased from 526 to $322 \mathrm{mg} \mathrm{kg}^{-1}$ with increasing soil depth, and under the soybean rhizosphere, from 473 to $211 \mathrm{mg} \mathrm{kg}^{-1}$ (Figure 4). There were significant differences between the two crops for this variable, in the 0 to $10-, 30$ to 40 - and 40 to $50-\mathrm{cm}$-soil layers. In the two latter layers such differences were even larger as a result of the greater amount of decomposing or unshapely roots in the maize crop (Figure 3). The microbial C was increased by the maize root system stimulation, since it reached deeper soil layers in comparison to the soybean system. This effect was also evidenced by a higher microbial $\mathrm{C} /$ total $\mathrm{C}$ ratio $\left(\mathrm{C}_{\text {mic }}\right.$ : $\mathrm{C}_{\text {total }}$ ) observed in these deeper layers. In short, there was higher quantity of available $C$ in these layers under maize cropping for the formation and maintenance of the microbial biomass, than for the soybean crop.

The $\mathrm{C}_{\text {mic }}: \mathrm{C}_{\text {total }}$ ratio pratically did not decrease as soil depth increased, since this ratio varied from 26 to 25 $\mathrm{mg}$ :g for the maize, and from 25 to $18 \mathrm{mg}$ : $\mathrm{g}$ for the soybeans. On the other hand Sparling (1992) and Haynes (1999) reported a decrease in the $\mathrm{C}_{\text {mic }}: \mathrm{C}_{\text {total }}$ ratio with increasing soil depth in a soil under temperate climate. The present research results are, however, in agreement with the ones obtained by Venzke Filho (1999) and Sá (2001) in the same area of the present study. Recent results obtained by Balota et al. (2003) show that $\mathrm{C}_{\text {mic }}: \mathrm{C}_{\text {total }}$ ratio remains constant with increasing soil depth under the conventional system, but the ratio depends on the used rotation crop sequence under the no-tillage system. When the crop sequence was maize-wheat rotated with cottonwheat, the $\mathrm{C}_{\text {mic }}: \mathrm{C}_{\text {total }}$ ratio decreased with the soil depth. Meanwhile, when soybeans-wheat was used, the ratio did not alter with soil depth. Nevertheless, soil samplings in these mentioned research works were not done in the presence of the active root systems, what might have in-

Table 1 - C and N quantities in different classes of maize and soybean roots cultivated in a soil under no-tillage system.

\begin{tabular}{|c|c|c|c|c|c|c|}
\hline \multirow{2}{*}{ Root classes } & \multicolumn{3}{|c|}{ Maize } & \multicolumn{3}{|c|}{ Soybeans } \\
\hline & $\mathrm{C}$ & $\mathrm{N}$ & $\mathrm{C} / \mathrm{N}$ & $\mathrm{C}$ & $\mathrm{N}$ & $\mathrm{C} / \mathrm{N}$ \\
\hline & - & -- $\mathrm{kg} \mathrm{ha}^{-1}$ & - & - & -- $\mathrm{kg} \mathrm{ha}^{-1}$ & - \\
\hline Thin & $84 \pm 4^{*}$ & $4.3 \pm 0.2$ & 20 & $90 \pm 4$ & $4.5 \pm 0.2$ & 20 \\
\hline Thick & $112 \pm 15$ & $4.5 \pm 0.6$ & 25 & $50 \pm 6$ & $1.6 \pm 0.2$ & 31 \\
\hline In decomposition & $1127 \pm 89$ & $49.2 \pm 3.9$ & 23 & $252 \pm 22$ & $14.6 \pm 1.3$ & 17 \\
\hline Total & 1323 & 58.0 & 23 & 392 & 20.7 & 19 \\
\hline
\end{tabular}

* Means \pm standard deviation (three trenchs).

Obs.: The root class "in decomposition” includes the unshapely roots. 
fluenced the results, because the soil C-content entering via rhizodeposits was not taken into account.

The soil under maize presented higher total Ccontent than under soybeans, in the $0-10$ and $40-50 \mathrm{~cm}$ soil layers (Figure 4) and higher total- $\mathrm{N}$ in the three deeper layers. The small increases in the $\mathrm{C}$ and $\mathrm{N}$ contents in these soil layers probably result from the higher rhizodeposition and root renovation of maize plants along the crop cycle, since the quantity of rhizodeposits produced by the plants are proportional to the total $\mathrm{C}$ fixed by the plant (Bolton Jr. et al., 1993).

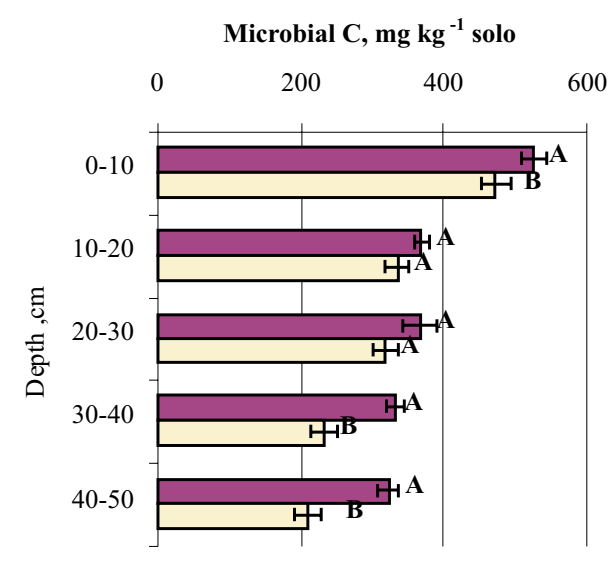

Cmic : Ctotal (mg : g)
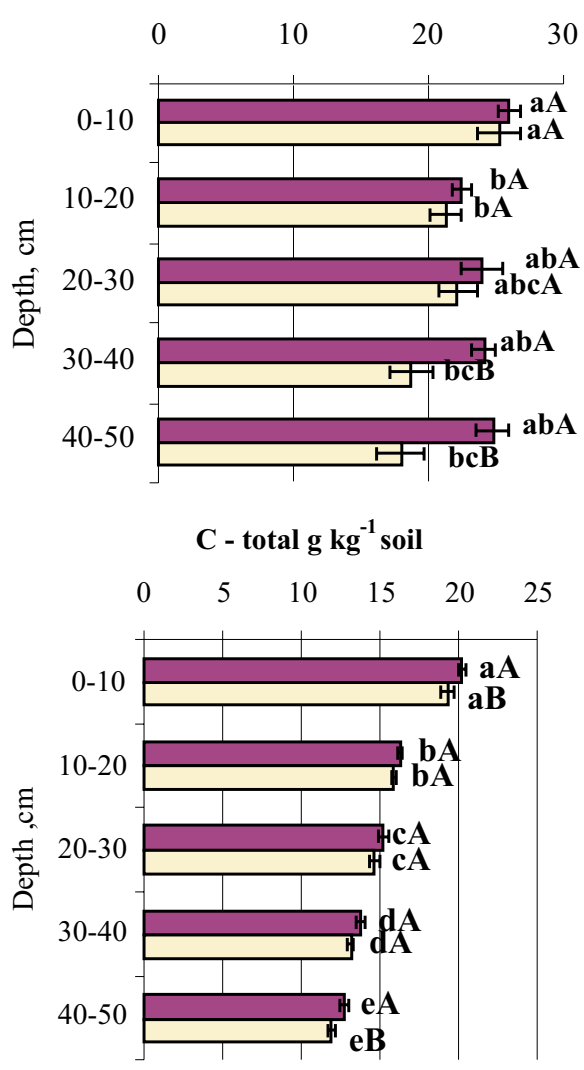

The soil microbial $\mathrm{N}$ contents decreased with increasing soil depth for both crops (Figure 4); for the maize crop, the decrease was from 54 to $21 \mathrm{mg} \mathrm{kg}^{-1}$, and for soybeans, from 71 to $28 \mathrm{mg} \mathrm{kg}^{-1}$. Higher soil microbial $\mathrm{N}$ contents were found for the soybeans than for the maize, for the $0-10,10-20$ and $40-50 \mathrm{~cm}$ soil layers. Legume species rhizosphere stimulated the growth of gramnegative bacteria more than fungi. This bacterial growth is favored by the soybean rhizodeposition, rich in aminoacids (Ayers \& Thornton, 1968; Vancura \& Hanzlikova, 1972; Jones, 1999) and soluble sugars
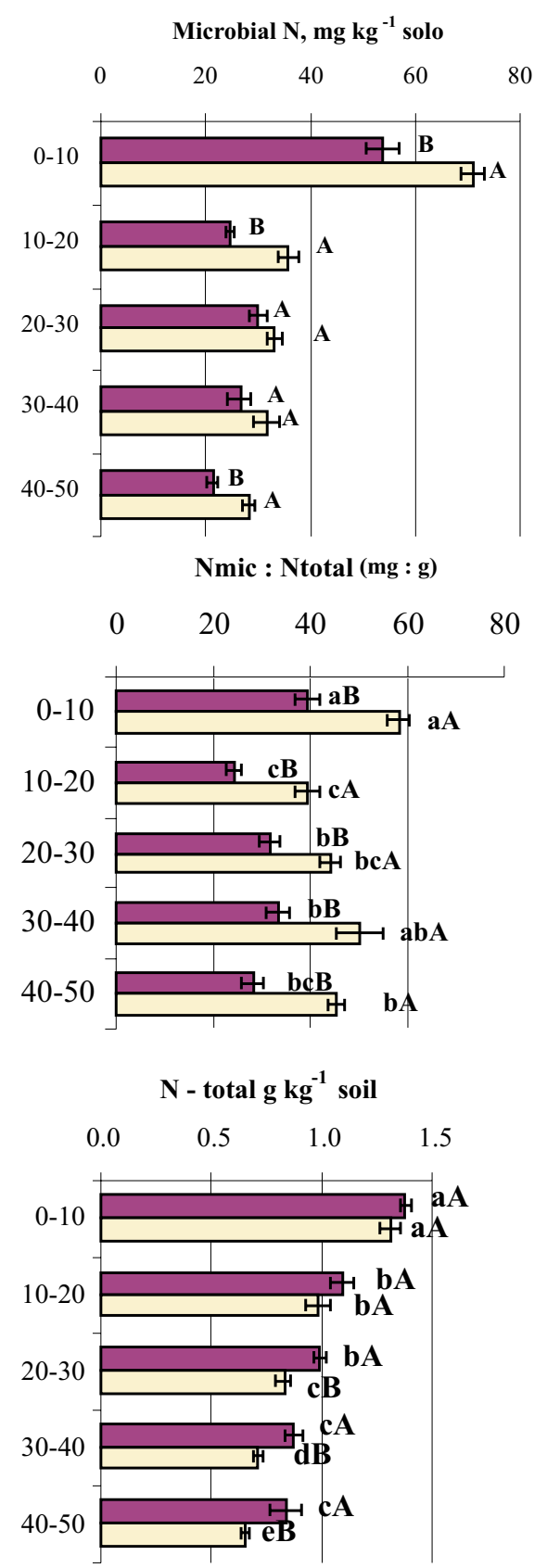

Maize

Figure 4 - Microbial C and N contents and their relation with total soil C and N, influenced by the maize and soybean root systems cultivated in a soil under no-tillage system (average of three replications). Means \pm standard deviations followed by the same capital letters in the same depth and small letters between depths do not difer by the Student's T test (0.05). 
(Jensen, 1996); the resistance to antibiotics, abundant in the rhizosphere due to the microorganisms antagonism (Moreira \& Siqueira, 2002); and the rather slow fungi growth rate observed, in general, in artificial growth media. Influenced by all these factors, bacteria grows faster in the soil under the root effect, and may significantly contribute to the increase in the soil microbial $\mathrm{N}$ in the rhizosphere, due to their lower $\mathrm{C}: \mathrm{N}$ ratio compared to fungi (Hunt et al., 1987).

The soil microbial-N/ total-N ratio $\left(\mathrm{N}_{\text {mic }}: \mathrm{N}_{\text {total }}\right)$ was higher under the soybean than under the maize, for all soil layers. A quantitative alteration might have occurred in the microbial community due to the root effect. Actually several studies point that plants are the main determinant agent of the soil microbial community structure (Rovira, 1959; Miller et al., 1989; Grayston et al., 1998). This increase in the $\mathrm{N}_{\text {mic }}: \mathrm{N}_{\text {total }}$ ratio for the soybean cropping may benefit the subsequent crop. According to McGrill et al. (1988), this ratio better expresses the $\mathrm{N}$ fraction more easily mineralizable than the microbial $\mathrm{N}$ quantity, what indicates that crops subsequent to soybeans will find soils with higher $\mathrm{N}$ mineralization potential than they would find after maize cropping.

\section{Relations between microbial $\mathrm{C}$ and $\mathrm{N}$ and the maize and soybean root parameters}

The correlations found between the root parameters and microbial $\mathrm{C}$ and $\mathrm{N}$ were not high (below $r=0.60$ ). The root length density (RLD) for the maize crop showed negative correlation with the microbial $\mathrm{C}$ content $(r=-0.21 ; P=0.01 ; \mathrm{n}=120)$ and positive with the microbial $\mathrm{N}(r=0.27 ; P=0.01 ; \mathrm{n}=120)$. The higher maize root concentrations probably altered the microbial $\mathrm{C}: \mathrm{N}$ ratio, because of the interference in the microbial community composition.

Most rhizotron or in vitro studies demonstrate increase of bacteria around growing roots (Bolton Jr. et al., 1993; Grayston et al., 1998) and mycorrhiza (Andrade et al., 1998). These bacteria attract predators such as protozoa and bacteriophage nematodes. The protozoa consume the bacteria, mobilizing about $1 / 3 \mathrm{~N}$ of the bacterial biomass, which is released in the $\mathrm{NH}_{4}^{+}$form, available to the roots (Clarholm, 1989). Specific studies on the trophic chain and on the change in the microbial community composition and in the microfauna under the influence of the root system during the legumes or grasses cycles are necessary, to understand the several energy and nutrient flows paths in agricultural soil.

The soybean total RLD (thin + thick roots) did not present significant correlation with microbial $\mathrm{C}$ or $\mathrm{N}$ contents. The soybean thin-root RLD showed correlation only with the microbial $\mathrm{N}(r=0.36 ; P=0.001 ; \mathrm{n}=120)$, while the soybean thick-root RLD showed correlation only with the microbial $\mathrm{C}$, indicating that thin roots are responsible for a higher effect on the microbial $\mathrm{N}$ than on the microbial C contents. Thin roots are more physiologically active and have greater ability of releasing exudates in their extremities than thicker roots, whith the main function of plant sustentation. In wheat, the apices are the root parts where the elongation occurs and also the release of organic compounds (Rovira, 1979; Campbell \& Greaves, 1990). However, the rhizodepositions may also occur in other locations (Bolton Jr. et al., 1993). Therefore soil areas with higher concentration of thin roots will more likely present higher microbial $\mathrm{N}$ contents.

The maize root dry matter density (RDMD) did not correlate with the microbial C, but did correlate with microbial $\mathrm{N}$ content and with the $\mathrm{N}_{\text {mic }}: \mathrm{N}_{\text {total }}$ ratio $(r=0.35$ and $r=0.40$, respectively, $P=0.001, \mathrm{n}=120$ ). The soybean RDMD presented low correlations with the microbial C and $\mathrm{N}$ contents ( $r=0.30$ and $r=0.34$, respectively, $P=0.001, \mathrm{n}=120$ ). This seems to indicate an effect of active root concentration on the microbial $\mathrm{N}$ for both crops, and on the microbial C for soybean roots only.

Root diameter did not present any correlation with the microbial C or $\mathrm{N}$ contents. Nevertheless, root diameter may perhaps be an important factor for the microbial community since the channels formed by root decomposition will give way for gas exchanges and water infiltration in the soil, what will benefit the subsequent crop root system expansion (Cannell, 1981; Kemper \& Derpsch, 1981).

The soybean decomposing or unshapely roots showed linear correlation with the microbial $\mathrm{C}$ content ( $r=0.33 ; P=0.01 ; \mathrm{n}=120)$, but no correlation was found between these two variables for the maize plants. However, the decomposing roots presented the highest correlations with the microbial $\mathrm{N}$ contents: $r=0.53$ $(P=0.01 ; \mathrm{n}=120)$ for the maize crop; and $r=0.53$ $(P=0.01 ; \mathrm{n}=120)$ for the soybeans. The senescent root system enhances the microbial $\mathrm{N}$, because they have enough available $\mathrm{C}$ and $\mathrm{N}$ for microbial growth and, besides, present the lowest C:N ratio (Table 1). As a consequence, the enhanced microbial biomass may compete, at first, with the maize plants for the mineral N, making it unavailable, because the decomposing roots present C: $\mathrm{N}$ ratio around 17-23:1 (Table 1). At any rate, this is a better balanced substrate than the straw.

\section{CONCLUSIONS}

Cropping soybeans and maize under no-tillage system induced differentiated effects over the microbial biomass. The maize roots enhanced the microbial $\mathrm{C}$ contents in the deeper soil layers, while the soybean roots enhanced the microbial $\mathrm{N}$. The maize, as a C4 plant, presented higher relative root dry matter yield than soybeans, however, the percent distribution of root dry matter in the soil profile was similar in both crops under no-tillage sys- 
tem. The thin roots and decomposing or unshapely roots were the root parameters that better expressed the effect of the root system of both crops over the soil microbial $\mathrm{N}$. The cultivation of plants with differentiated morphological characteristics, like grasses $\left(\mathrm{C}_{4}\right)$ and legumes $\left(\mathrm{C}_{3}\right)$, beneficiate the no-tillage system because they alternate the effects over the physical characteristics (drainage channels, amount of dry matter incorporated in the deeper soil layers) and the soil biological characteristics (availability of labile $\mathrm{N}$ ).

\section{ACKNOWLEDGEMENTS}

To Maria Flávia Gonçalves, Andréia Perin, Daniela Tuturati (UNIMEP, Piracicaba), trainees at the Environmental Biogeochemistry Laboratory (CENA,USP) for the help with the chemical and physical analysis of roots and soil.

\section{REFERENCES}

ANDRADE, G.; LINDERMAN, R.G.; BETHLENFALVAY, G.J. Bacterial associations with the mycorrhizosphere and hyphosphere of the arbuscular mycorrhizal fungus Glomus mosseae. Plant and Soil, v.202, p.79-87, 1998.

AYRES, W.A.; THORNTON, R.H. Exudation of amino acids by intact and damaged roots of wheat and peas. Plant and Soil, v.28, p.193-207, 1968.

BALOTA, E.L.; COLOZZI-FILHO, A.; ANDRADE, D.S.; DICK, R.P. Microbial biomass in soil under different tillage and crop rotation systems. Biology and Fertility of Soils, v.38, p.15-20, 2003.

BARBER, S.A. Soil nutrient bioavailability - a mechanistic approach. New York: John Wiley \& Sons, 1995. 414p.

BILLES, G.; BOTTNER, P. Living roots effects on ${ }^{14} \mathrm{C}$ carbon isotopelabelled root litter decomposition. Plant and Soil, v.62, p.193-208, 1981.

BOHM, W. Methods of studying root systems. New York: Springer-Verlag, 1979. 189p.

BOLTON Jr., H.; FREDERICSON, J.K.; ELLIOT, L.F. Microbial ecology of the rhizosphere. In: METTING Jr., F.B. (Ed.) Soil microbial ecology: applications in agricultural and environmental management. New York: Marcel Dekker, 1993. p.27-36.

BROOKES, P.C.; LANDMAN, A.; PRUDEN, G.; JENKINSON, D.S. Chloroform fumigation and the release of soil nitrogen. Soil Biology and Biochemistry, v.17, p.837-847, 1985.

CAMBPELL, R.; GREAVES, M.P. Anatomy and Community structure of the rhizosphere. In: LYNCH, J.M. The rhizosphere. Chichester: John Wiley \& Sons, 1990. cap.2, p.11-34.

CANNELL, R.Q. Soil cultural practices related to root development. In: RUSSELL, R.S.; IGUE, K.; MEHTA, Y.R. (Ed.) The soil/root system in relation to Brazilian agriculture. Londrina: Fundação Instituto Agronômico do Paraná, 1981. p.61-80.

CARTER, M.R. Influence of reduced tillage systems on organic matter, microbial biomass, macro-aggregate distribution and structural stability of surface soil in a humid climate. Soil \& Tillage Research, v.23, p.361372, 1992.

CATTELAN, A.J.; VIDOR, C. Flutuações na biomassa, atividade e população microbiana do solo, em função de variações ambientais. Revista Brasileira Ciência do Solo, v.14, p.133-142, 1990.

CHENG, W.; COLEMAN, D.C. Effect of living roots on soil organic matter decomposition. Soil Biology and Biochemistry, v.22, p.781-788, 1990.

CLARHOLM, M. Effects of plant-bacterial-amoebal interactions on plant uptake of nitrogen under field conditions. Biology and Fertility of Soils, v.8, p.373-378, 1989.

CRESTANA, S.; GUIMARÃES, M.F.; JORG, L.A.C.; RALISH, R.; TOZZI, C.L.; TORRE, A.; VAZ, C.M.P. Avaliação da distribuição de raízes no solo auxiliada por processamento de imagens digitais. Revista Brasileira de Ciência do Solo, v.18, p.365-371, 1994.
CUENCA, G.; ARANGUREN, J.; HERRARA, R. Root growth and litter decomposition in a coffee plantation under shade trees. Plant and Soil, v.71, p.477-486, 1983.

FANTE Jr. L. Sistema radicular da aveia forrageira avaliado por diferentes métodos, incluindo processamento de imagens digitais. Piracicaba: USP/ ESALQ, 1997. 119p. (Tese - Doutorado).

FEHR, W.R.; CAVINESS, C.E.; BURMOOD, D.T.; PENNINGTON, J.S. Stage of development description for soybean (Glycine max (L.) Merrill). Crop Science, v.11, p.929-931, 1971.

FISHER, F.M.; GOSZ, J.R. Effect of trenching on soil processes and properties in a New Mexico mixed-conifer forest. Biology and Fertility of Soils, v.2, p.35-42, 1986.

GALE, W.J.; CAMBARDELLA, C.A. Carbon dynamics of surface residueand root-derived organic matter under simulated no-till. Soil Science Society of America Journal, v.64, p.190-195, 2000.

GRAYSTON, S.J.; WANG, S.; CAMPBELL, C.D.; EDWARDS, A.C. Selective influence of plant species on microbial diversity in the rhizosphere. Soil Biology \& Biochemistry, v.30, p.369-378, 1998.

HAYNES, R.J. Size and activity of the soil microbial biomass under grass and arable management. Biology and Fertility of Soils, v.30, p.210216, 1999.

HUNT, H.W.; COLEMAN, D.C.; INGHAM, ELLIOTT, E.T.; MOORE, J.C.; ROSE, S.L.; REID, C.P.P.; MORLEY, C.R. The detrital food web in a shortgrass prairie. Biology and Fertility of Soils, v.3, p.57-68, 1987.

JENKINSON, D.S. Studies on the decomposition of plant material in soil: $\mathrm{V}$. The effect of plant cover and soil types on the loss of ${ }^{14} \mathrm{C}$-labelled ryegrass decomposing under field conditions. Soil Science Society of America Journal, v.28, p.424-434, 1977.

JENSEN, E.S. Rhizodeposition of $\mathrm{N}$ by pea and barley and its effect on soil N dynamics. Soil Biology \& Biochemistry, v.28, p.65-71, 1996.

JOERGENSEN, R.G.; BROOKES, P.C Ninhydrin-reative nitrogen measurements of microbial biomass in $0,5 \mathrm{M} \mathrm{K}_{2} \mathrm{SO}_{4}$ soil extracts. Soil Biology and Biochemistry, v.22, p.1023-1027, 1990.

JONES, D.L. Amino acid biodegradation and its potential effects on organic nitrogen capture by plants. Soil Biology and Biochemistry, v.31, p.613622, 1999.

KEMPER, B.; DERPSCH, R. Soil compaction and root growth in Paraná. In: RUSSELL, R.S.; IGUE, K.; MEHTA, Y.R. (Ed.) The soil/root system in relation to Brazilian agriculture. Londrina: Fundação Instituto Agronômico do Paraná, 1981. p.81-100

LYNCH, J.M. Limits of microbial growths in soil. Journal of General Microbiology, v.128, p.405-410, 1982.

Mc GRILL, W.B.; DORMAAR, J.E.; REINL-DWYER, E. New perspective on soil organic matter quality, quantity and dynamics on the Canadian prairies. In: ANNUAL MEETING ON LAND DEGRADATION AND CONSERVATION TILLAGE, 34., Calgary, 1988. Proceedings. Calgary: CSSS; AIC, 1988. p.30-38.

MILLER, H.J.; HENKEN, G.; van VEEN, J.A. Variation and composition of bacterial populations in rhizosphere of maize, wheat and grass cultivars. Canadian Journal of Microbiology, v.16, p.656-660, 1989.

MOREIRA, F.M.S.; SIQUEIRA, J.O. Microbiologia e bioquímica do solo. Lavras: Editora UFLA, 2002. 626p.

QIAN, J.H.; DORAN, J.W.; WALTERS, D.T. Maize plant contributions to root zone available carbon and microbial transformations of nitrogen. Soil Biology and Biochemistry, v.29, p.1451-1462, 1997.

ROVIRA, A.D. Root excretions in relation to the rhizosphere effect: IV. Influence of plant species, age of plant, light, temperature, and calcium nutrition on exudation. Plant and Soil, v.36, p.53-64, 1959.

ROVIRA, A.D. Biology of the soil-root interface. In: HARLEY, J.L.; RUSSELL, R.S. (Ed.) The soil root interface. New York: Academic Press, 1979. p.145-160.

SÁ, J.C. de M. Dinâmica da matéria orgânica do solo em sistemas de manejo convencional e plantio direto. Piracicaba: USP/ESALQ, 2001. 141p. (Tese - Doutourado).

SÁ, J.C.M.; CERRI, C.C.; DICK, W.A.; LAL, R.; VENZKE FILHO, S.P.; PICCOLO, M.C.; FEIGL, B.E. Organic matter dynamic and carbon sequestration rates for a tillage chronosequences in a Brazilian Oxisol. Soil Science Society of America Journal, v.65, p.1486-1499, 2001.

SAS Institute. SAS/STAT guide for personal computers: Version 6. Cary: SAS Institute, 1987. 1v. 
SCHURMANN, J.J.; GOEDEWAAGEN, M.A.J. Methods for the examination of root systems and roots. 2.ed. Wageningen: Pudoc, 1971. 86p.

SHIERLAW, J.; ALSTON, A.M. Effect of soil compaction on root growth and uptake pf phosphorus. Plant and Soil, v.77, p.15-28, 1984.

SPARLING, G.P. Ratio of microbial biomass to soil organic carbon as a sensitive indicator of change in soil organic matter. Australian Journal of Soil Research, v.30, p.195-207, 1992.

SPARLING, G.P.; WEST, A.W. A direct extraction method to estimate soil microbial C: calibration in situ using microbial respiration and ${ }^{14} \mathrm{C}$ labeled sells. Soil Biology and Biochemistry, v.20, p.337-343, 1988.

SPARLING, G.P.; CHESHIRE, M.V.; MUNDIE, C.M. Effect of barley plants on the decomposition of ${ }^{14} \mathrm{C}$-labelled soil organic matter. Soil Science Society of America Journal, v.33, p.89-100, 1982.

SPARLING, G.P.; GRUPTA, V.V.S.R.; ZHU, C. Release of ninhydrinreactive compounds during fumigation of soil to estimate microbial $\mathrm{C}$ and N. Soil Biology and Biochemistry, v.25, p.1803-1805, 1993.

STALEY, T.E.; EDWARDS, C.L.; SCOTT, C.L.; OWENS, L.B. Soil microbial biomass and organic component alterations in a no-tillage chronosequence. Soil Science Society of America Journal, v.52, p.9981000, 1988.
TORMENA, C.A. Efeito do tráfego de máquinas em propriedades físicas do solo. In: CURSO SOBRE MANEJO DO SOLO NO SISTEMA PLANTIO DIRETO, Castro, 1995. Anais. Castro: Fundação ABC, 1996. p.52-77.

VANCE, E.D.; BROOKES, P.C.; JENKINSON, D.S. An extraction method for measuring soil microbial biomass C. Soil Biology and Biochemistry, v.19, p.703-707, 1987.

VANCURA, V.; HANZLIKOVA, A. Root exudates of plants IV. Differences in chemical composition of seed and seedling exudates. Plant and Soil, v.36, p.271-282, 1972.

VENZKE FILHO, S.P. Microbiota e sua atividade em uma cronossequência sob sistema plantio direto. Piracicaba: USP/ESALQ, 1999. 65p. (Dissertação - Mestrado).

Received October 02, 2003

Accepted June 14, 2004 